\title{
An Apology for Postmodern Prose
}

There are almost no dogs in $\mathrm{Oz}$. Or rather, there are no real dogs. There are police dogs. And sheep dogs. And drug-sniffing dogs and watch dogs and show dogs. But there are no car-chasing dogs. No flower-bed-digging dogs, no garbage-can-upsetting dogs. No, need it be said, poet dogs. The streets are very clean and traffic moves at the speed of commerce. Which is to say, as fast and smooth as a clear-running brook. In the bookstores, which are as ubiquitous as coffee shops (for they are one and the same), the art of giving the customer what he or she wants has become so refined that there are no books available that are not wanted by everyone. The young accept this as a state of nature, and in fact, it is the result of a sort of evolution: in the early days, a book would be displayed on a shelf only so long as it sold at a certain popular level. But as the speed of commerce increased, and the business of books (plural) decreased the time any one book (singular) might remain on a shelf, the bookshelves themselves began to lengthen, then move, evolving into extremely long conveyor belts that carried books directly from printing presses through the stores where customers were compelled to quickly pluck off the titles they wanted the way they might select sushi from a passing boat in a Japanese restaurant. As with raw fish, freshness became a dominant concern, so instead of re-circulating back through the kitchen then out past the customers again, books that no one had plucked from the stream on a single pass continued, as they do to this day, on their one-way journey to the recycling plant. There they are shredded, and turned into products people might find more useful, such as greeting cards or the paper cups used in the coffee shops that take up most of the actual square footage of each bookstore. Since movies, art and all forms of entertainment are sold in exactly this way, culture has become like time in Oz-always the same, though no customer can ever dip his or her toe into the same stream twice. And without anyone even noticing, dogs, real dogs, somehow vanished. 
Official Prose Culture

I'm talking about a prose equivalent to what poet Charles Bernstein refers to as "official verse culture," which we might think of as the types of stories and novels that dominate academic literary magazines, and bookstore shelves (107). That is, the kind of fiction Granta editor Ian Jack was dismayed to have dominate the list of candidates submitted to him and the other final judges charged with the task of identifying the Best Young American Writers: "well-behaved" fiction that fellow judge Robert Stone characterized as "a kind of 'social realism'...the educated American's alternative to religious revivalism" with its "penitential tone...insistence on seriousness...dislike of 'elitism'...obsessive pursuit of 'authenticity' and a narodnik romance with the land and ordinary people" (13).

This is the type of literature that Jed Rasula claims can be most clearly understood as a commodity based on a now specious "ideology of privacy," a kind of literature that adheres to the following principles:

1) it must demonstrate a restraint of the stimulations or aggressions that inhere in charged or intense language; 2) it must display fidelity to the poet's [novelist's] personal life; 3) this fidelity, this "being true to life" must affirm a certain sufficiency inherent in all of us; 4) it must be an innocuous artifact and in no way seek to challenge its status as the private concern of a handful of consumers. (Perloff 19)

Indeed, in the aggregate, the producers of "the literature of naïve mimesis," as Malcom Bradbury calls it, constitute a de facto conglomerate: Rasula's "Poetry Systems Incorporated," a business whose main product is "known as the 'self'...readily available in popular magazines and at chain bookstores," and whose "corporate newsletter"' is "the New York Times Book Review" (Perloff 19-20).

This, of course, isn't to say that the art of ideas and the art of mimesis are mutually exclusive. Nor that conceptual lit never gets published by or reviewed in the commercial press. It certainly isn't to say that any work with Postmodern affinities has the aesthetic high-ground; just as mimetic paintings of pastel sunsets and clip- 
per ships on the high seas are as plentiful as Hallmark cards, so Postmodern kitsch is as common as MTV. Generally, though, the more conceptual a work of fiction, the rougher its reception. Sometimes non-mimetic work will be singled out for being boring and unreadable as New York Times critic James Atlas calls David Foster Wallace, John Barth, and Thomas Pynchon (as well as Proust, Joyce, and James). Often oranges are condemned for not being apples, the term 'postmodern' itself used as a synonym for anything bad. Perhaps more subtly, as David Radavich points out, in the absence of literary radicalism and experimentation, an ethos

Reasons for Novels Being Good, Wonderful, Deserving, Etc. -According to The New York Times Book Review

-According to The Review of Contemporary Fiction

...life has been illuminated, washed in an elegiac, graceful and forgiving light....

There is a wonderful sweetness to this novel....

[The Author] has done his homework on midwifery and the mechanics of childbirth. He has also landed on a hot topic for baby boomers...

Reasons for Novels Being Bad, Difficult, Not Worth Bothering About, Etc.

I smelled magic realism....

In another sort of novel, [the character] might be inspired to atone for sins..

...her book affords little sense of real people struggling with real problems.... matures within writing programs where the "literary marketplace" becomes the "primary objective and arbiter of value" (110, 111).

One would think that the university would be a hotbed of literary radicalism and experimentation. But in fact, as Curtis White argues, the great wash of "creative writing" instructors and stu-

dents, as they are called in the academy, fail to see how the emphasis on craft, especially the well-crafted conventions of realism in the service of the Eternal Human Heart, operates hand-in-glove with commercial concerns and thereby reinforces the status quo-and simultaneously perpetuates an antique literature. Alain RobbeGrillet's 1956 observation that most novelists of the time could insert passages from old books into their novels "without awakening the suspicions" of the reading public seems equally valid today (16). And like Robbe-Grillet we might wonder why form in the novel should remain "fixed, when everything around it" is "in evolution - even revolution" (10). Or as William Gass put it, while the forms of mainstream architecture, art, and music have all built upon earlier forms to create an idiom that resonates with both contemporary thought and audiences, the "dominant form of the 2oth century novel has been the 19th century novel" (Bérubé B4).

So, what ever happened to the idea that literature was as much about how a work was written - its form - as about what it says? 
That a novel- both in form and content- should be a vehicle for exploring ways of looking at the world? Why has author education shifted from Gertrude Stein's school of Fractured Perspective to Radavich's exemplary professor who "prides himself on preparing his writing students just as a baseball coach readies a team for the major leagues," transforming their "idiosyncratic writing, or 'sandlot baseball,' into something more mainstream and marketable for publication, 'The Field of Dreams'" (109). Why are the partisans of craft so untroubled, as Robbe-Grillet thought they must be, by the "resemblance of their arguments, their vocabulary, their values to those of the most hardened bourgeois critics," especially in "the matter of separating the 'form' of a novel from...the anecdote it serves to report" (41-42), doing what comes naturally, as White puts it, completely satisfied with their own position of the "adequate and proper" (22). Never asking, as does Gass, why it's so hard to write tragedy in limerick.

The way that reviewers, readers, distributors, and the rest of a book's environment can serve as its co-author has always been obvious in totalitarian countries. In the USSR, generations of authors made careers cranking out social realist novels while idiosyncratic writers like Andrey Platonov, writers whose style questioned the Section E.3 All motion picture, television and allied rights in and to TITLE OF NOVEL written by Seller shall be frozen until the date eight (8) months after the initial release or broadcast of the Motion Picture unless Company and Seller enter into an agreement regarding Company's acquisition of such rights during the "freeze" period. If no such agreement is reached, Company shall thereafter have a right of first negotiation/matching last refusal to acquire such rights from Seller as set forth in Paragraph 7 of the Standard Terms and Conditions...

- Standard Author/Publisher Contract assumptions of Official

Soviet Prose Culture, were only able to survive by giving up writing, as did Platonov, so that he might take the job assigned him by the Soviet bureaucracy: doorman at the Writers' Union Club in Moscow. Now that our own alternative delivery systems (government subsidies, not-for-profit presses) have been squeezed into oblivion, it's become starkly evident what an influential co-author commerce has always been in capitalist countries.

The nineteenth-century novel is sociologist Howard Becker's illustrative case. The fact that authors were paid by the word and the novels serialized in magazines so influenced their writing that these business practices helped define what we think of as the nineteenth-century novel: a book with an episodic plot that is fat 
enough to use as a doorstop. Similarly, the ability to easily translate a novel into a movie with mass demographics, where the real money is, is shaping what we think of as a novel at the turn of our century. And also what a novel is not, as the author of a conceptual novel (potential sales of 1,400 copies) learns when she (and not an agent, agents knowing better) approaches one of the five publishing conglomerates that comprise mainstream publishing (say Time Warner's Warner Books and Little Brown) that bought the memoir of Paula Barbieri (O.J. Simpson's girlfriend) for $\$ 3$ million (with a print run of 300,000 copies) and is looking for a way to recoup.

"Courses that teach poetry, fiction and drama writing can offer students valuable insights and experience," writes Radavich, "but only if creative writing classes are brought into deeper and wider relation with other courses in the curriculum; only if such programs maintain a pedagogy not geared toward packaging for the marketplace but instead emphasizing reading skills, critical thinking, language awareness, and historical consciousness, qualities and abilities that will prove useful in many walks of life..." (112). Yet instead of working toward the kind of integration Radavich imagines, creative-writers often seem more concerned with "taking back English departments from the theorists," or, to speak unspoken hegemonic desires, returning the critic/scholar to the service of the poet/novelist, returning English departments to an earlier pastoral conception of literature, when perhaps a more significant literature might result from creative writing programs that participated in the rethinking, reordering, re-theorizing underway in all of the humanities, including that literature, a.k.a. texts, that have no dust jacket, no bookends-literature without library or bookstore walls. Even if this means for writers of prose to abandon the teaching of craft and the well-crafted cuckoo clock the word implies. Even if it entails authors of prose joining, as Guy Debord puts it, the "empty space, the antimatter, of consumer society" that is poetry (Rothenberg 418). At least some poetry. At least some prose.

A proposition: Postmodern prose is the most discursive of art forms, and therefore highly suited to an examination of the contemporary conscience of competing discourse systems, of language practice, i.e., in Plato's terms, of right knowledge, or how 
things work. It does so by transgressing generic boundaries, this quality itself being the most commonly re-marked marker of what our society has codified as Postmodernism, even more so than poetry; for while very few poems contain novels, it is not uncommon for a novel (or an essay) to contain a poem as well as other forms of discourse that are the bricks in our invisible cities: joking, the ritual language of administration and law; the language practices of the National Enquirer and The New York Times; of the twoparty politician, and of the third and fourth party politician; scientific writing; philology and apology, the text of the travelogue, and of the catalog.... But beyond this, by the logic Dennis Barone claims that "every realist work is conservative no matter who writes it," (235) because of this hybrid nature, every pomo novel is about discourse no matter who writes it (students included). The more consciously this attention to discourse is placed at the center, that is, the more commercial concerns are submerged in order to emphasize reading skills, critical thinking, language awareness, historical consciousness, the more the work will be about how things work; the Postmodern novel, conceptual novel-call it what you will-the anti-generic narrative is inherently discursive as discourse itself becomes the subject, no matter what the theme. Rather than assuming that man, or commerce, is the measure of all things, it opens up this field to posit this self not as an essential given, but as a premise that is as in flux as language, time and culture. And if, as Tzvetan Todorov maintains, a genre is only a genre if it is historically perceived as such, i.e., if it exists by dint of social agreement, to deconstruct the genre is to deconstruct the society in which it is found. Which is to say, of course, that there is compelling reason to welcome into this mix the genre of realist, traditional story telling and its humanist underpinnings. For obviously, Social Realism, too, is a genre. Indeed it is the genre of choice for the majority of authors and readers, perhaps for its very insistence of the self. It forms a rearguard, or if you prefer, Oulipian constraint against complete subjectivity during our paradigm shift. Or who can say, maybe it is the vanguard of a turn away from the abyss back to a re-entrenchment in the Eternal Human Heart. For the human heart, like the perpetual calendar, does seem to be eternal. And one only need think of those glorious nineteenth-century novels to be reminded, as Joseph Tabbi notes, that 
the novel is the vehicle best suited to "organizing vast amounts of information into patterns possessing cognitive value and coherence" (3). Even in a contingent world we need coherence. We need continuity, we need each other, even if, as Umberto Eco claims, a sophisticated man can no longer tell a sophisticated woman "I love you madly," Barbara Cartland's 70o+ romance novels having done their share to siphon those words of the innocence they require, even if the sentiment they can no longer express remains as passionate as ever (73-74).

My apology for Postmodern prose is not a plea for authors to fixate on any one way to write so much as a plea for an awareness of the play of discourse and literary history all writing embodiesand the importance of aesthetic decisions to real humans. To consider the unspoken baggage carried by every way of speaking/writing. Just as there is no such thing as Postmodern, but only postmoderns, it is an appeal to conceive of literature as a yes and both; craft and anti-craft, critique and sentiment; a matter of both talking heads and sunsets. Or as poet Nicanor Parra fashions himself, a matter of "asserting the anti-poet as fellow (counter)-worker with the more familiar poet" (Rothenberg 407).

So let us end with a prayer to one patron saint:

Blessed Andrey Platonov

Doorman of the Soviet Writer's Union

Hold open for us the catalog of every $B \& N$

Though we walk shirtless, shoeless

Through the Valley of No Shirt, No Shoes, No Service

Lead us not into temptation

For we do not want an art that only serves

Two masters, Yea! a multitude (No Pets!)

Only grant us right knowledge

Remember to us that

Writing is a form of knowing

Knowing is a form of being

To teach writing is to teach be-think-ing

(with heart)

Forever and ever

(or if you prefer, from lack of an origin to non-end) Amen 